\title{
Pengaruh Person Organization Fit dan Workplace Spirituality Terhadap Turnover Intention dengan Affective Commitment sebagai Variabel Intervening dan Generasi Millennial sebagai Moderasi (Studi Kasus PT Bank Tabungan Negara)
}

\author{
Nevi Nevada \\ Universitas Airlangga \\ e-mail: nevinevada@gmail.com
}

\begin{abstract}
This study aims to determine the effect of person organization fit and workplace spirituality on turnover intention through affective commitment as an intervening variable. Also, to determine the relationship between person organization fit on turnover intention moderated by millennials generation, Samples in this study are employees of PT Bank Tabungan Negara, Tbk., total of 100 respondents. This type or research is explanatory with quantitative methods. The sampling technique used is nonprobability sampling with purposive sampling, namely the technique of sampling data source with certain considerations. This study uses a survey method using a questionnaire in data collection and processed using Partial Least Squares. The results of the testing of hypothesis indicate that there is a negative effect of person organization fit on turnover intention, There is a negative effect of workplace spirituality on turnover intention. There is a positive effect of person organization fit and workplace spirituality on affective commitment. There is negative effect of affective commitment on turnover intention. There is an effect of person organization fit and workplace spirituality on turnover intention through affective commitment. There is a relationship between person organization fit on turnover intention moderated by millennials generation.
\end{abstract}

Keywords: person-organization fit, workplace spirituality, affective commitment, millennials generation, turnover intention

\section{PENDAHULUAN}

Tidak dapat dipungkiri bahwa sumber daya manusia masih mendapatkan perhatian yang cukup serius karena merupakan pilar utama sekaligus roda penggerek sebuah organisasi dalam upaya mewujudkan visi dan misinya. Meskipun organisasi memiliki modal hingga sarana prasarana yang baik namun tidak memiliki sumber daya manusia yang mendukung maka segala kegiatan yang terjadi di dalam organisasi tersebut tidak akan terselesaikan dengan baik. Oleh karena itu, organisasi berlomba-lomba untuk mendapatkan, mempertahankan, dan mengembangkan sumber daya manusia sebagai sumber daya yang memiliki potensi untuk dikembangkan. Sumber daya manusia tersebut seiring dengan tumbuhnya organisasi yang akan diisi oleh beberapa generasi, salah satunya generasi milenial.

Karyawan generasi milenial mulai mendapatkan perhatian di segala lini perusahaan. Hal ini dikarenakan jumlah karyawan generasi milenial yang semakin bertambah setiap tahunnya. Generasi milenial diprediksikan akan mendominasi sekitar lebih dari 50\% angkatan kerja di seluruh dunia pada tahun 2020 (Novita, 2017). Di Indonesia, jumlah generasi ini telah mencakup lebih dari 30\% dari total penduduk di tahun 2015 dan pada tahun 2016 meningkat menjadi 40\% dari total penduduk Indonesia (Panindya, 2017).

Diprediksikan bahwa jumlah tenaga kerja generasi milenial akan mencapai puncaknya, yaitu sebesar 70\% di tahun 2030 (Ali, 2016). Generasi 
milenial adalah mereka yang lahir sekitar tahun 1980-2000-an. generasi milenial cenderung memiliki ciri seperti cerdas, kreatif, produktif, berorientasi pada pencapaian prestasi (achievement oriented), mencari pengembangan personal, kebermaknaan karier, dan mencari mentor atau supervisor untuk mendorong dan memfasilitasi pengembangan profesionalitas (Kicheva, 2017). Oleh karena itu, apabila perusahaan tidak mampu menyediakan, memenuhi dan menyesuaikan lingkungan pekerjaan dengan kekhasan yang dimiliki oleh generasi tersebut maka generasi milenial sepenuhnya siap untuk mencari tempat lain. Sebaliknya, jika mereka merasa dihargai ada kemungkinan mereka bisa menjadi karyawan seumur hidup bagi perusahaan (Tanner, 2010). Oleh karena itu, masalah yang seringkali muncul terkait dengan isu generasi milenial tersebut adalah terkait dengan turnover.

Kondisi yang sama dihadapi oleh Bank BTN Surabaya. PT Bank Tabungan Negara merupakan Badan Usaha Milik Negara (BUMN) yang bergerak pada sektor perbankan. PT Bank Tabungan Negara, Tbk. (Bank BTN) adalah bank yang unggul dalam bidang kredit pembiayaan perumahan. Beberapa produk kredit pembiayaan rumah tersebut adalah kredit pemilikan rumah (KPR) BTN subsidi dan kredit pemilikan rumah (KPR) BTN platinum (non-subsidi).

Terjadinya turnover adalah suatu hal yang tidak diinginkan oleh perusahaan. Namun turnover merupakan masalah atau kejadian yang sering terjadi di sebuah perusahaan. Turnover dapat diartikan sebagai bentuk perbuatan karyawan yang keluar dari organisasi. Turnover menuju pada kenyataan akhir yang dialami suatu organisasi yaitu jumlah karyawan yang meninggalkan organisasi pada periode tertentu. Keinginan karyawan untuk berpindah (turnover intention) terlihat pada hasil evaluasi individu mengenai kelanjutan hubungan dengan organisasi yang belum terwujud dalam tindakan pasti meninggalkan organisasi (Rachmah, 2017). Tingginya turnover karyawan pada perusahaan mengakibatkan tingginya biaya perekrutan, seleksi, dan pelatihan yang harus ditanggung oleh perusahaan (Mercer, 1988). Tentunya hal tersebut dapat mengganggu efisiensi operasional bila karyawan yang meninggalkan organisasi memiliki pengetahuan dan pengalaman sehingga perusahaan memerlukan persiapan dan biaya untuk mencari penggantinya. Menurut Michaels dan Spectoe (1982) terdapat tiga hal yang dapat digunakan untuk pengukuran turnover intention sebagai berikut.

1. Adanya pikiran untuk keluar (thinking of quitting), mencerminkan individu untuk berpikir keluar dari pekerjaan atau tetap berada di lingkungan kerja.

2. Adanya keinginan untuk mencari alternatif pekerjaan (intention to search for alternatives), mencerminkan keinginan individu untuk mencari pekerjaan di organisasi lain.

3. Adanya keinginan untuk keluar (intention to quit), mencerminkan individu yang berkeinginan untuk keluar.

Mathis dan Jackson (2006) menggambarkan bahwa upaya dalam mempertahankan karyawan untuk tetap pada tempat kerjanya merupakan persoalan yang menjadi tantangan bagi suatu perusahaan $\mathrm{Hal}$ ini dikarenakan mencari tenaga kerja/karyawan yang berbakat atau sesuai dengan perusahaan tidaklah mudah. Salah satu cara yang dapat dilakukan untuk meminimalisasi adanya keinginan karyawan untuk keluar dari perusahaan adalah dengan memastikan kesesuaian antara organisasi dengan karyawan (Kristof, 1996). Kristof mengaitkan proses seleksi pada penelitian human resource management (HRM) tentang person organization fit.

Person-organization fit (P-O fit) dapat membantu perusahaan untuk memilih para karyawan 
Nevi Nevada, Pengaruh Person Organization Fit dan Workplace Spirituality Terhadap Turnover Intention dengan Affective Commitment sebagai Variabel Intervening dan Generasi Millennial sebagai Moderasi

dengan nilai dan keyakinan yang sesuai dengan organisasi dan membentuk pengalaman-pengalaman yang dapat memperkuat kesesuaian tersebut. Suatu organisasi membutuhkan P-O fit, karena P-O fit adalah kunci untuk mempertahankan tenaga kerja yang fleksibel dan berkomitmen. Di mana person organization fit didefinisikan sebagai kesesuaian antara orang dan organisasi di mana ia bekerja, dengan kata lain mengacu pada kompatibilitas antara seseorang dan organisasi atau perusahaan, menekankan sejauh mana seseorang dan karakteristik organisasi memiliki kesesuaian yang dapat memenuhi kebutuhan keduanya, baik karyawan maupun organisasi atau perusahaan (Behery, 2009). Menurut Kristof (1996), variable Person-organization fit dibentuk oleh indikator yang dapat diartikan dalam empat konsep sebagai berikut.

1. Kesesuaian nilai (value congruence), yaitu kesesuaian antara nilai intrinsik individu dengan organisasi.

2. Kesesuaian tujuan (goal congruence), yaitu kesesuaian antara tujuan individu dengan organisasi dalam hal ini adalah pemimpin dan rekan sekerja.

3. Pemenuhan kebutuhan karyawan (employee need fulfilment) adalah kesesuaian antara kebutuhan-kebutuhan karyawan dan kekuatan yang terdapat dalam lingkungan kerja dengan sistem dan struktur organisasi. Kekuatan yang terdapat dalam lingkungan kerja.

4. Kesesuaian karakteristik kultur-kepribadian (culture personality congruence) adalah kesesuaian antara kepribadian (non-nilai) dari setiap individu dan iklim atau kultur organisasi.

Selain person organization fit faktor yang menentukan generasi milenial bertahan di perusahaan adalah workplace spirituality. Ashmos and Duchon (2000) menjelaskan bahwa spiritualitas di tempat kerja merupakan kondisi yang dimiliki karyawan berupa "kehidupan batin" yang berkaitan dengan pekerjaan dan komunitas. Dengan kata lain, jika karyawan menemukan makna di dalam pekerjaannya dikarenakan pekerjaannya memberikan dampak bagi masyarakat luas serta lingkungan kerja yang saling mendukung antar-karyawan maka akan menimbulkan rasa suka cita serta kenyamanan untuk berada di organisasi tersebut. Menurut As Ashmos and Duchon (2000), variabel workplace spirituality dibentuk oleh indikator yang dapat diartikan dalam tiga konsep sebagai berikut.

1. Kehidupan Batin (inner life), adalah pemahaman mengenai kekuatan ilahi dan bagaimana cara menggunakannya untuk kehidupan lahiriah yang lebih memuaskan.

2. Makna dan tujuan bekerja (meaning and purpose in work), adalah hidup maupun bekerja yang menyangkut kehidupan dengan makna, tujuan, kedamaian, dan perasaan memiliki kontribusi terhadap komunitas yang lebih luas. Spiritualitas di tempat kerja menyangkut bagaimana membawa hidup dan pekerjaan berjalan bersama.

3. Perasaan terhubung dengan komunitas (a sense connection and community). Workplace spirituality tidak hanya bagaimana mengekspresikan kebutuhan-kebutuhan batin dengan mencari pekerjaan yang bermakna melainkan bagaimana hidup dapat terhubung dengan orang lain.

Person organization fit dan workplace spirituality juga dapat meningkatkan komitmen karyawan. Ketika karyawan sudah sesuai dengan nilai-nilai, budaya, dan tujuan organisasi serta sudah menemukan makna dari pekerjaannya maka akan timbul perasaan memiliki sehingga tidak ingin melewatkan keistimewaan yang diberikan oleh perusahaan/organisasi atau dengan kata lain karyawan secara tidak langsung telah terikat 
komitmen secara afektif dengan perusahaan. Komitmen afektif menggambarkan attachment emosional karyawan pada organisasinya (Allen Meyer, 1996). Seperti yang diketahui bahwa komitmen karyawan sangat dibutuhkan oleh sebuah perusahaan, karena dapat meningkatkan kinerja yang berdampak pada perusahaan dan karyawan juga akan terlibat secara sukarela dalam berbagai kegiatan yang diadakan perusahaan sehingga perusahaan akan lebih mudah untuk mencapai tujuan perusahaan. Di samping itu, karyawan yang memiliki komitmen pada organisasi tidak akan berniat meninggalkan organisasi.

\section{Rumusan Masalah}

Berdasarkan pada latar belakang yang telah diungkapkan sebelumnya, rumusan masalah dalam penelitian ini adalah sebagai berikut.

1. Apakah person organization fit berpengaruh terhadap turnover intention pada pegawai Bank Tabungan Negara?

2. Apakah workplace spirituality berpengaruh terhadap turnover intention pada pegawai Bank Tabungan Negara?

3. Apakah person organization fit berpengaruh terhadap affective commitment pada pegawai Bank Tabungan Negara?

4. Apakah workplace spirituality berpengaruh terhadap affective commitment pada pegawai Bank Tabungan Negara?

5. Apakah affective commitment berpengaruh terhadap turnover intention pada pegawai Bank Tabungan Negara?

6. Apakah affective commitment memediasi hubungan antara person organization fit terhadap turnover intention pada pegawai Bank Tabungan Negara?

7. Apakah affective commitment memediasi hubungan antara workplace spirituality terhadap turnover intention pada pegawai Bank Tabungan Negara?

8. Apakah Generasi Milenial memoderasi hubungan antara person organization fit terhadap turnover intention?

\section{KERANGKA BERPIKIR DAN METODE PE- NELITIAN}

Berikut merupakan kerangka pemikiran yang dapat menjelaskan hubungan antar-konsep yang digunakan untuk menyusun penelitian.

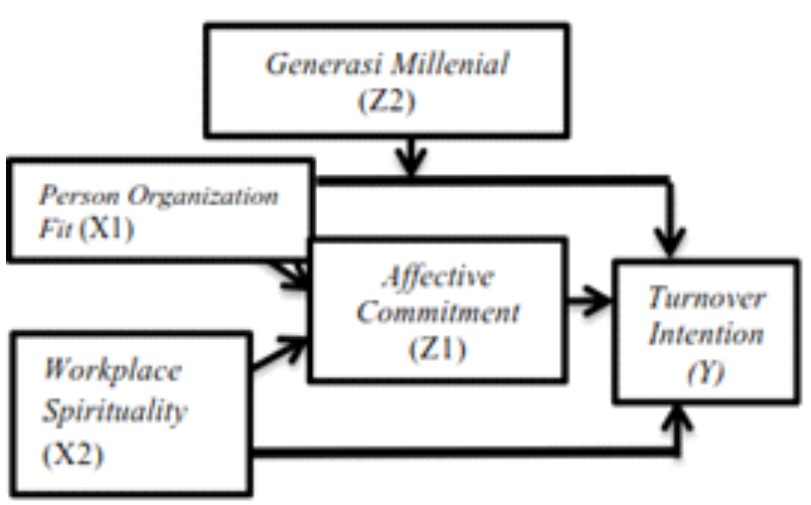

\section{Jenis Penelitian}

Jenis penelitian yang digunakan adalah eksplanatori. Adapun penelitian eksplanatori menurut Sugiyono (2017) adalah penelitian yang menjelaskan hubungan kausal antara variabel-variabel yang memengaruhi hipotesis. Sementara di dalam penelitian ini menggunakan pendekatan kuantitatif karena diperlukan perhitungan yang sistematis atas pengaruh antar-variabel yang berfokus pada pengujian hipotesis dan hasilnya dapat digeneralisasikan dan dapat menghasilkan data yang lebih terukur dengan bantuan aplikasi statistik.

\section{Populasi dan Sampel}

Populasi adalah generalisasi yang terdiri dari objek/subjek yang mempunyai kuantitas dan karakteristik tertentu yang ditetapkan oleh pene- 
Nevi Nevada, Pengaruh Person Organization Fit dan Workplace Spirituality Terhadap Turnover Intention dengan Affective Commitment sebagai Variabel Intervening dan Generasi Millennial sebagai Moderasi

liti untuk dipelajari dan kemudian ditarik kesimpulannya (Sugiyono, 2017). Populasi yang digunakan dalam penelitian ini adalah seluruh karyawan yang bekerja di PT Bank Tabungan Negara. Sementara sampel adalah bagian dari jumlah dan karakteristik yang dimiliki oleh populasi tersebut. Pengambilan sampel yang benar-benar dapat mewakili dan dapat menggambarkan populasi sebenarnya. Untuk menentukan sampel yang akan digunakan dalam penelitian, terdapat berbagai teknik sampling yang digunakan. Sehingga jumlah responden yang ada dalam penelitian ini sebanyak 100 orang. Dalam penelitian ini teknik sampling yang digunakan yaitu nonprobability sampling dengan teknik purposive sampling. Menurut Sugiyono (2017) bahwa non-probability sampling adalah teknik pengambilan sampel yang tidak memberi peluang atau kesempatan sama bagi setiap unsur atau anggota populasi untuk dipilih menjadi sampel. Teknik sampel ini meliputi sampling sistematis, kuota, aksidental, purposive, jenuh, dan snowball. Sementara purposive sampling adalah teknik pengambilan sampel sumber data dengan pertimbangan tertentu. Alasan menggunakan teknik purposive sampling adalah karena tidak semua sampel memiliki kriteria yang sesuai dengan fenomena yang diteliti.

\section{Teknik Pengumpulan Data}

Teknik pengumpulan data yang digunakan dalam penelitian ini adalah dengan menyebarkan kuesioner. Sumber data yang diperoleh adalah data primer yang didapatkan dari responden yang bekerja di PT Bank Tabungan Negara, Tbk. dengan menyebarkan kuesioner secara online.

\section{Skala Pengukuran Data}

Perhitungan kuesioner dengan menggunakan skala pengukuran likert memakai penilaian skor
1-5. Skala likert digunakan untuk mengukur sikap, pendapat, dan persepsi seseorang atau sekelompok orang tentang fenomena sosial. Jawaban responden mengenai Person-organization fit (PO-fit), workplace spirituality, affective commitment, turnover intention, dan generasi millennial akan dijelaskan dengan melihat standar deviasi dan mean. Untuk dapat dikategorikan jawaban dari responden maka akan digunakan interval kelas yang dicari dengan rumus sebagai berikut.

Dari rumus tersebut, interval kelas akan ditentukan dengan data sebagai berikut.

Tabel 1 Kategori Rata-Rata Jawaban Responden

\begin{tabular}{|l|l|}
\hline \multicolumn{1}{|c|}{ Interval } & \multicolumn{1}{|c|}{ Kategori } \\
\hline $1,00 \leq \mathrm{x} \leq 1,80$ & Sangat Rendah \\
\hline $1,81 \leq \mathrm{x} \leq 2,60$ & Rendah \\
\hline $2,61 \leq \mathrm{x} \leq 3,40$ & Sedang \\
\hline $3,41 \leq \mathrm{x} \leq 4,20$ & Tinggi \\
\hline $4.21 \leq \mathrm{x} \leq 5,00$ & Sangat Tinggi \\
\hline
\end{tabular}

\section{Teknik Analisis Data}

Penelitian ini menggunakan pendekatan structural equation modeling. Analisis SEM yang digunakan adalah partial least square (PLS) dengan menggunakan program software SmartPLS (Ringle, Wende, \& Will, 2005.

\section{Uji Validitas}

Pada penelitian ini uji validitas dilakukan dengan menggunakan program SmartPLS versi 3.0 untuk menguji convergent validity dan discriminant validity.

\section{Uji Reliabilitas}

Uji reliabilitas dapat menggunakan dua metode, yaitu Cronbach's alpha dan Composite reliability. Cronbach's alpha digunakan untuk 
mengukur batas bawah nilai reliabilitas sebuah konstruk. Composite reliability dinilai lebih baik dalam mengestimasi internal suatu konstruk. Composite reliability yang memiliki nilai di atas 0,70 maka dapat dikatakan bahwa konstruk dinyatakan reliabel. Berdasarkan hasil uji reliabilitas yang sudah dilakukan, menunjukkan bahwa variabel person organization fit, workplace spirituality, affective commitment, turnover intention dan generasi millennial memenuhi persyaratan uji reliabilitas sehingga ketiga variabel tersebut dapat dikatakan reliabel.

\section{HASIL PENELITIAN DAN PEMBAHASAN}

Dalam rangka mewujudkan visi dan misi Bank Tabungan Negara, insan-insan Bank Tabungan Negara perlu menerapkan nilai-nilai organisasi dalam berperilaku dan melakukan pekerjaannya. Setiap karyawan diharapkan menerima dan menyepakati nilai-nilai yang dimaksud jika bergabung dengan Bank Tabungan Negara, yang kemudian disebut dengan budaya organisasi. Budaya organisasi tersebut adalah SIIPS (sinergi, integritas, inovasi, profesionalisme, dan spirit mencapai keunggulan).

\section{Karakteristik Responden}

Tabel 2 Jumlah Responden Berdasarkan Jenis Kelamin

\begin{tabular}{|c|c|c|c|}
\hline No. & $\begin{array}{c}\text { Jenis } \\
\text { Kelamin }\end{array}$ & $\begin{array}{c}\text { Jumlah } \\
\text { (Orang) }\end{array}$ & $\begin{array}{c}\text { Persentase } \\
\text { (\%) }\end{array}$ \\
\hline 1 & Laki-laki & 63 & $63 \%$ \\
\hline 2 & Perempuan & 37 & $37 . \%$ \\
\hline & Jumlah & 100 & $100 \%$ \\
\hline
\end{tabular}

Berdasarkan Tabel 2 dapat diketahui bahwa dari 100 subjek penelitian, mayoritas responden laki-laki lebih banyak daripada responden perempuan. Jumlah responden laki-laki berjumlah 63 orang (63\%), kemudian responden yang berjenis kelamin perempuan berjumlah 37 orang (37\%).
Tabel 3 Karakteristik Usia Responden

\begin{tabular}{|c|c|c|c|}
\hline No. & Usia & $\begin{array}{c}\text { Jumlah } \\
\text { (Orang) }\end{array}$ & $\begin{array}{c}\text { Persentase } \\
\mathbf{( \% )}\end{array}$ \\
\hline 1 & $24-30$ tahun & 19 & $19 \%$ \\
\hline 2 & $31-36$ tahun & 28 & $28 \%$ \\
\hline 3 & $37-42$ tahun & 23 & $23 \%$ \\
\hline & $>42$ tahun & 30 & $30 \%$ \\
\hline & Jumlah & 100 & $100 \%$ \\
\hline
\end{tabular}

Berdasarkan Tabel 3 dapat diketahui bahwa dari 100 subjek penelitian, responden yang berusia 24 sampai 30 tahun berjumlah 19 orang (19\%), responden yang berusia 31 sampai 36 tahun berjumlah 28 orang (28\%), responden yang berusia 37 sampai 42 tahun 23 orang (23\%), sementara responden yang berusia di atas 42 tahun sebanyak 30 orang (30\%).

Tabel 4 Karakteristik Berdasarkan Pendidikan

\begin{tabular}{|c|c|c|c|}
\hline No. & Pendidikan & $\begin{array}{c}\text { Jumlah } \\
\text { (Orang) }\end{array}$ & $\begin{array}{c}\text { Persentase } \\
(\mathbf{\%})\end{array}$ \\
\hline 1 & D3 & 5 & $5 \%$ \\
\hline 2 & S1 & 78 & $78 \%$ \\
\hline 3 & S2 & 17 & $17 \%$ \\
\hline & Jumlah & 100 & $100 \%$ \\
\hline
\end{tabular}

Dapat diketahui bahwa dari 100 subjek penelitian dalam penelitian ini mayoritas responden adalah lulusan $\$ 1$ yaitu berjumlah 78 orang (78\%), kemudian responden dengan lulusan S2 berjumlah 17 orang (17\%), responden dengan lulusan D3 berjumlah 5 orang (5\%). Hal tersebut dapat dilihat pada Tabel 4.

Tabel 5 Karakteristik Berdasarkan Lama Bekerja

\begin{tabular}{|c|c|c|c|}
\hline No. & Lama Bekerja & $\begin{array}{c}\text { Jumlah } \\
\text { (Orang) }\end{array}$ & $\begin{array}{c}\text { Persentase } \\
(\%)\end{array}$ \\
\hline 1 & $1-3$ tahun & 6 & $6 \%$ \\
\hline 2 & $4-6$ tahun & 11 & $11 \%$ \\
\hline 3 & $7-10$ tahun & 30 & $30 \%$ \\
\hline 4 & $10>$ tahun & 53 & $53 \%$ \\
\hline & Jumlah & 100 & $100 \%$ \\
\hline
\end{tabular}


Nevi Nevada, Pengaruh Person Organization Fit dan Workplace Spirituality Terhadap Turnover Intention dengan Affective Commitment sebagai Variabel Intervening dan Generasi Millennial sebagai Moderasi

Berdasarkan Tabel 5 dapat diketahui bahwa dari 100 subjek penelitian dalam penelitian ini dapat diketahui sebanyak enam orang $(6 \%)$ telah bekerja di Bank Tabungan Negara Selama 1-3 tahun, sebanyak 11 orang (11\%) telah bekerja di Bank Tabungan Negara selama 4-6 tahun, sebanyak 30 orang (30\%) telah bekerja di Bank Tabungan Negara selama 7-10 tahun, sebanyak 53 orang (53\%) telah bekerja di Bank Tabungan Negara selama lebih dari 10 tahun.

Tabel 6 Karakteristik Responden Berdasarkan Status

\begin{tabular}{|c|l|c|c|}
\hline No. & \multicolumn{1}{|c|}{ Status } & $\begin{array}{c}\text { Jumlah } \\
\text { (Orang) }\end{array}$ & $\begin{array}{c}\text { Persentase } \\
(\mathbf{\%})\end{array}$ \\
\hline 1 & Menikah & 63 & $63 \%$ \\
\hline 2 & Belum menikah & 37 & $37 \%$ \\
\hline & Jumlah & 100 & $100 \%$ \\
\hline
\end{tabular}

Berdasarkan Tabel 6 dapat diketahui bahwa dari 100 subjek penelitian, responden yang berstatus menikah berjumlah 63 orang (63\%), sementara responden yang berstatus belum menikah berjumlah 37 orang (37\%).

\section{Deskripsi Jawaban Responden}

Tabel 7 Hasil Rata-Rata Tanggapan Responden Terhadap Variabel Person Organization Fit

\begin{tabular}{|l|c|c|}
\hline \multicolumn{1}{|c|}{ Indikator } & Mean & Kategori \\
\hline $\begin{array}{l}\text { PO1: Saya memiliki nilai- } \\
\text { nilai yangsesuai dengan } \\
\text { organisasi ini }\end{array}$ & 3.53 & Tinggi \\
\hline $\begin{array}{l}\text { PO2: Tujuan organisasi } \\
\text { sudahmencerminkan tuju- } \\
\text { an saya }\end{array}$ & 3.49 & Tinggi \\
\hline $\begin{array}{l}\text { PO3: Nilai-nilai dan bu- } \\
\text { daya organisasi sesuai de- } \\
\text { ngan hal-hal yang saya } \\
\text { hargai dalam hidup }\end{array}$ & 3.86 & Tinggi \\
\hline Mean Total & $\mathbf{3 , 6 2}$ & Tinggi \\
\hline
\end{tabular}

Berdasarkan hasil tersebut, nilai mean atau rata-rata dari jawaban responden terhadap variabel person organization fit adalah sebesar 3.62 yang termasuk dalam kategori tinggi. Hal ini mengindikasikan bahwa pegawai Bank Tabungan Negara memiliki kesesuaian nilai-nilai, harapan dan karakteristik pribadi yang dimiliki dengan organisasi tempat pegawai tersebut bekerja yaitu Bank Tabungan Negara.

Tabel 8 Hasil Rata-Rata Tanggapan Responden Terhadap Variabel Workplace Spirituality

\begin{tabular}{|l|c|c|}
\hline \multicolumn{1}{|c|}{ Indikator } & Mean & Kat. \\
\hline $\begin{array}{l}\text { WPS1: Di tempat kerja } \\
\text { terdapat ruangan untuk } \\
\text { beribadah/kerohanian saya }\end{array}$ & 3.34 & Tinggi \\
\hline $\begin{array}{l}\text { WPS2: Berdoa adalahbagian } \\
\text { penting dalamhidup saya }\end{array}$ & 3.52 & Tinggi \\
\hline $\begin{array}{l}\text { WPS3: Saya senang menjalani } \\
\text { pekerjaansaya }\end{array}$ & 3.54 & Tinggi \\
\hline $\begin{array}{l}\text { WPS4: Pekerjaan saya sesuai } \\
\text { dengan prinsiphidup saya }\end{array}$ & 3.59 & Tinggi \\
\hline $\begin{array}{l}\text { WPS5: Saya melihat terda- } \\
\text { pat hubunganantara peker- } \\
\text { jaan saya dengan kebaikan } \\
\text { sosial masyarakat yang lebih } \\
\text { besar dari organisasi saya }\end{array}$ & 3.69 & Tinggi \\
\hline $\begin{array}{l}\text { WPS6: Saya merasamenjadi } \\
\text { bagian dari sebuah komunis- } \\
\text { tasdi tempat saya bekerja }\end{array}$ & 3.65 & Tinggi \\
\hline $\begin{array}{l}\text { WPS7: Saya merasabahwa } \\
\text { anggota tim saya saling } \\
\text { m endukung satusama lain }\end{array}$ & 3.65 & Tinggi \\
\hline $\begin{array}{l}\text { WPS8: Saya merasabahwa } \\
\text { anggota tim saya peduli satu } \\
\text { sama lain }\end{array}$ & 3.54 & Tinggi \\
\hline $\begin{array}{l}\text { WPS9: Tim saya menunjuk- } \\
\text { kan semangat dari kekom- } \\
\text { pakan }\end{array}$ & 3.30 & Sedang \\
\hline Mean Total & 3.53 & Tinggi \\
\hline
\end{tabular}

Berdasarkan hasil tersebut, nilai mean atau rata-rata dari jawaban responden terhadap variabel workplace spirituality adalah sebesar 3.62 yang termasuk dalam kategori tinggi. Hal ini menunjukkan bahwa karyawan Bank Tabungan Negara merasa pekerjaan mereka memiliki makna serta pengaruh terhadap masyarakat luas sehingga secara tidak langsung akan menimbulkan rasa suka cita karyawan di tempat kerja. 
Pada akhirnya karyawan juga lebih dapat menikmati pekerjaan mereka dan lebih bisa mengekspresikan ide serta hasil kerja mereka, serta kontribusi yang tinggi terhadap komunitas.

Tabel 9 Hasil Rata-Rata Tanggapan Responden Terhadap Variabel Affective Commitment

\begin{tabular}{|l|c|c|}
\hline \multicolumn{1}{|c|}{ Indikator } & Mean & Kat. \\
\hline $\begin{array}{l}\text { AC1: Saya merasa organi- } \\
\text { sasi ini seperti 'keluarga } \\
\text { saya sendiri' }\end{array}$ & 3.87 & Tinggi \\
\hline $\begin{array}{l}\text { AC2: Saya merasakan } \\
\text { 'sense of belonging' yang } \\
\text { kuat terhadaporganisasi ini }\end{array}$ & 3.75 & Tinggi \\
\hline $\begin{array}{l}\text { AC3: Saya merasa seolah- } \\
\text { olah masalah organisasi ini } \\
\text { adalah masalah saya sendiri }\end{array}$ & 3.68 & Tinggi \\
\hline $\begin{array}{l}\text { AC4: Saya bangga memberi } \\
\text { tahu orang-orang bahwa } \\
\text { saya bagian dari organisasi } \\
\text { ini }\end{array}$ & 3.65 & Tinggi \\
\hline $\begin{array}{l}\text { AC5: Organisasi ini layak } \\
\text { mendapatkanloyalitas saya }\end{array}$ & 3.64 & Tinggi \\
\hline $\begin{array}{l}\text { AC6: Saya akan sangat se- } \\
\text { nang menghabiskan sisa ka- } \\
\text { rier saya di organisasi ini }\end{array}$ & 3.57 & Tinggi \\
\hline Mean Total & 3.69 & Tinggi \\
\hline
\end{tabular}

Berdasarkan Tabel 9, nilai mean dari jawaban responden terhadap variabel affective commitment adalah sebesar 3.69 yang mana termasuk dalam kategori tinggi. Hal ini menunjukkan bahwa pegawai Bank Tabungan Negara telah terikat secara afektif dengan organisasi. Karyawan dengan komitmen tinggi juga akan memberikan segala usaha, kemampuan dan loyalitasnya untuk mewujudkan nilai dan tujuan organisasi tersebut.

Tabel 10 Hasil Rata-Rata Tanggapan Responden Terhadap Variabel Turnover Intention

\begin{tabular}{|l|l|l|}
\hline \multicolumn{1}{|c|}{ Indikator } & Mean & \multicolumn{1}{c|}{ Kat. } \\
\hline $\begin{array}{l}\text { TI1: Saya sering berpikir } \\
\text { untuk meninggalkan per- } \\
\text { usahaan }\end{array}$ & 2.40 & Rendah \\
\hline
\end{tabular}

\begin{tabular}{|l|l|l|}
\hline $\begin{array}{l}\text { TI2: Saya sering mencoba } \\
\text { untuk mencaripekerjaan } \\
\text { baru di perusahaan lain }\end{array}$ & 2.50 & Rendah \\
\hline $\begin{array}{l}\text { TI3: Saya inginmeninggal- } \\
\text { kan perusahaan apabila } \\
\text { ada kesempatanyang lebih } \\
\text { baik }\end{array}$ & 2.57 & Rendah \\
\hline $\begin{array}{l}\text { TI4: Saya berkeinginan } \\
\text { untuk keluar dari peker- } \\
\text { jaan saya }\end{array}$ & 2.54 & Rendah \\
\hline $\begin{array}{l}\text { TI5: Saya berkeinginan un- } \\
\text { tuk meninggalkan perusa- } \\
\text { haan dalam waktu dekat }\end{array}$ & 2.48 & Rendah \\
\hline Mean Total & 2.49 & Rendah \\
\hline
\end{tabular}

Berdasarkan tabel tersebut, rata-rata jawaban responden terhadap variabel turnover intention adalah sebesar 2.49 yang mana masuk dalam kategori rendah. Hal ini mengindikasikan bahwa karyawan Bank BTN tidak berniat meninggalkan perusahaan atau organisasi, meskipun terdapat peluang yang lebih baik.

Tabel 11 Hasil Rata-Rata Tanggapan Responden Terhadap Variabel Generasi Millennial

\begin{tabular}{|c|c|c|}
\hline No. & Usia & $\begin{array}{c}\text { Jumlah } \\
\text { (Orang) }\end{array}$ \\
\hline 1 & $24-29$ tahun & 19 \\
\hline 2 & $30-35$ tahun & 28 \\
\hline 3 & $36-40$ tahun & 23 \\
\hline & $>40$ tahun & 30 \\
\hline & Jumlah & 100 \\
\hline
\end{tabular}

Berdasarkan hasil tersebut yang berasal dari Generasi Y sebanyak 68 orang, generasi Y merupakan generasi milenial yang lahir pada tahun 1980-2000, sementara pembandingnya adalah generasi X sebanyak 32 orang yang lahir pada tahun 1945-1979. Generasi milenial ini diukur dengan dummy, skor 0 untuk yang lahir di era milenial, skor 1 untuk yang lahir selain milenial. 
Nevi Nevada, Pengaruh Person Organization Fit dan Workplace Spirituality Terhadap Turnover Intention dengan Affective Commitment sebagai Variabel Intervening dan Generasi Millennial sebagai Moderasi

\section{Analisis Model Pengukuran atau Outer Model}

Analisis outer model berkaitan dengan pengujian validitas dan reliabilitas berbagai indikator dari variabel penelitian. Validitas indikator atau disebut outer model dalam PLS dievaluasi dengan menggunakan convergent dan discriminant validity. Reliabilitas dievaluasi melalui composite reliability dan cronbach alpha.

\section{Convergent Validity}

Uji convergent validity dalam PLS dapat dilakukan dengan melihat masing-masing loading factor. Nilai loading factor mendeskripsikan besarnya korelasi antara setiap item pengukuran (indikator pada kuesioner) dengan variabel laten (konstruknya). Satu item indikator dikatakan telah memenuhi convergent validity apabila skor loading pada tiap jalur (path) antara komponen (variabel laten) dan variabel manifest sebaiknya $>0.7$ (Jogiyanto, 2016). Berikut adalah nilai outer loading dari masing-masing indikator pada variabel penelitian.

Tabel 12 Loading Factor

\begin{tabular}{|l|c|c|}
\hline \multicolumn{1}{|c|}{ Variabel } & Indikator & $\begin{array}{c}\text { Outer } \\
\text { Loading }\end{array}$ \\
\hline $\begin{array}{l}\text { Person Organization } \\
\text { Fit (X1) }\end{array}$ & $\mathrm{X} 1.1$ & 0.856 \\
\cline { 2 - 3 } $\begin{array}{l}\text { Workplace } \\
\text { Spirituality (X2) }\end{array}$ & $\mathrm{X} 1.2$ & 0.864 \\
\cline { 2 - 3 } & $\mathrm{X} 2.1$ & 0.899 \\
\cline { 2 - 3 } & $\mathrm{X} 2.2$ & 0.820 \\
\cline { 2 - 3 } & $\mathrm{X} 2.3$ & 0.785 \\
\cline { 2 - 3 } & $\mathrm{X} 2.4$ & 0.851 \\
\cline { 2 - 3 } & $\mathrm{X} 2.5$ & 0.864 \\
\cline { 2 - 3 } & $\mathrm{X} 2.6$ & 0.808 \\
\cline { 2 - 3 } & $\mathrm{X} 2.7$ & 0.814 \\
\cline { 2 - 3 } & $\mathrm{X} 2.8$ & 0.797 \\
\cline { 2 - 3 } & $\mathrm{X} 2.9$ & 0.893 \\
\hline \multirow{4}{*}{$\begin{array}{l}\text { Turnover Intention } \\
\text { (Y) }\end{array}$} & $\mathrm{Y} 1$ & 0.643 \\
\cline { 2 - 3 } & $\mathrm{Y} 2$ & 0.746 \\
\cline { 2 - 3 } & $\mathrm{Y} 3$ & 0.707 \\
\cline { 2 - 3 } & $\mathrm{Y} 4$ & 0.735 \\
\cline { 2 - 3 } & $\mathrm{Y} 5$ & 0.704 \\
\hline
\end{tabular}

\begin{tabular}{|c|c|c|}
\hline \multirow{4}{*}{$\begin{array}{l}\text { Affective } \\
\text { Commitment (Z1) }\end{array}$} & $\mathrm{Z} 1.1$ & 0.781 \\
\hline & $\mathrm{Z} 1.2$ & 0.849 \\
\hline & Z1.3 & 0.877 \\
\hline & Z1.4 & 0.888 \\
\hline \multirow{2}{*}{$\begin{array}{l}\text { Affective } \\
\text { Commitment (Z1) }\end{array}$} & Z1.5 & 0.872 \\
\hline & Z1.6 & 0.589 \\
\hline $\begin{array}{l}\text { Generasi Millennial } \\
(\mathrm{Z} 2)\end{array}$ & $\mathrm{Z} 2.1$ & 1.176 \\
\hline
\end{tabular}

Berdasarkan tabel tersebut telah ditunjukkan bahwa masing-masing indikator dan variabel penelitian banyak yang memiliki nilai outer loading $>0.7$. Namun, terlihat masih terdapat beberapa indikator yang memiliki nilai outer loading $<0.7$. Menurut Ghozali (2012), nilai outer loading antara 0,5-0,6 sudah dianggap cukup untuk memenuhi syarat convergent validity. Data tersebut menunjukkan tidak ada indikator variabel yang nilai outer loading-nya di bawah 0,5 sehingga semua indikator dinyatakan layak atau valid untuk digunakan penelitian dan dapat digunakan untuk analisis lebih lanjut.

\section{Discriminant Validity}

Uji discriminant validity menggunakan nilai cross loading. Suatu indikator dinyatakan memenuhi discriminant validity apabila nilai cross loading indikator pada variabelnya adalah yang terbesar dibandingkan pada variabel lainnya (Ghozali,1998). Berikut ini adalah nilai cross loading masing-masing indikator.

Tabel 13 Cross Loading

\begin{tabular}{|c|c|c|c|c|c|}
\hline Var & AC & PO-F & $\begin{array}{c}\text { POF }^{*} \\
\text { GEN }\end{array}$ & TI & WPS \\
\hline AC1 & 0.781 & 0.574 & 0.386 & -0.561 & 0.526 \\
\hline AC2 & 0.849 & 0.560 & 0.450 & -0.688 & 0.618 \\
\hline AC3 & 0.877 & 0.519 & 0.513 & -0.740 & -0.740 \\
\hline AC4 & 0.888 & 0.492 & 0.420 & -0.727 & 0.646 \\
\hline AC5 & 0.872 & 0.539 & 0.428 & -0.694 & 0.635 \\
\hline AC6 & 0.589 & 0.273 & 0.278 & -0.488 & 0.522 \\
\hline PO1 & 0.554 & 0.856 & 0.431 & -0.550 & 0.436 \\
\hline PO2 & 0.500 & 0.864 & 0.428 & -0.558 & 0.376 \\
\hline
\end{tabular}




\begin{tabular}{|c|c|c|c|c|c|}
\hline PO3 & 0.518 & 0.855 & 0.479 & -0.582 & 0.419 \\
\hline $\begin{array}{c}\text { PO-F* } \\
\text { GEN }\end{array}$ & 0.512 & 0.520 & 1.000 & -0.663 & 0.621 \\
\hline TI1 & -0.404 & -0.416 & -0.471 & 0.643 & -0.448 \\
\hline T12 & -0.585 & -0.451 & -0.536 & 0.746 & -0.654 \\
\hline TI3 & -0.552 & -0.392 & -0.445 & 0.707 & -0.575 \\
\hline TI4 & -0.631 & -0.471 & -0.492 & 0.735 & -0.648 \\
\hline TI5 & -0.636 & -0.579 & -0.409 & 0.704 & -0.595 \\
\hline WPS1 & 0.690 & 0.461 & 0.567 & -0.809 & 0.899 \\
\hline WPS2 & 0.649 & 0.406 & 0.598 & -0.719 & 0.820 \\
\hline WPS3 & 0.733 & 0.444 & 0.546 & -0.725 & 0.785 \\
\hline WPS4 & 0.678 & 0.358 & 0.485 & -0.689 & 0.851 \\
\hline WPS5 & 0.614 & 0.396 & 0.607 & -0.707 & 0.864 \\
\hline WPS6 & 0.578 & 0.423 & 0.488 & -0.682 & 0.808 \\
\hline WPS07 & 0.559 & 0.414 & 0.441 & -0.636 & 0.814 \\
\hline WP508 & 0.539 & 0.328 & 0.377 & -0.546 & 0.797 \\
\hline WP509 & 0.636 & 0.358 & 0.529 & -0.728 & 0.893 \\
\hline
\end{tabular}

Tabel 13 menunjukkan bahwa nilai masingmasing indikator di suatu konstruk lebih tinggi dibandingkan dengan konstruk lain dan mengumpul pada satu konstruk tersebut. Oleh karena itu, dalam penelitian ini dapat dikatakan memiliki discriminant validity yang baik. Selain mengamati nilai cross loading, discriminant validity juga dapat diketahui melalui metode lainnya yaitu dengan melihat nilai average variant extracted (AVE) untuk masing-masing indikator dipersyaratkan nilainya harus $>0.5$ untuk model yang baik (Ghozali,1998).

Tabel 14 Average Variant Extracted (AVE)

\begin{tabular}{|l|c|}
\hline \multicolumn{1}{|c|}{ Variabel } & AVE \\
\hline Affective Commitment & 0.666 \\
\hline POV $^{*}$ Generasi & 1.000 \\
\hline Person Organization Fit & 0.737 \\
\hline Turnover Intention & 0.501 \\
\hline WPS & 0.702 \\
\hline
\end{tabular}

Berdasarkan sajian data dalam Tabel 14 diketahui bahwa nilai AVE variabel affective commitment, generasi, person organization fit, turnover intention, dan workplace spirituality $>0.5$. Dengan demikian dapat dinyatakan bahwa setiap variabel telah memiliki discriminant validity yang baik.

\section{Composite Reliability}

Uji reliabilitas dapat dilihat dari nilai cronbach's alpha dan composite reliability. Suatu konstruk dapat dikatakan reliabel apabila memiliki nilai cronbach's alpha harus $>0,6$ dan milai composite reliability harus $>0.7$ (Jogiyanto, 2016). Composite reliability mengukur nilai reliabilitas sesungguhnya dari suatu variabel sedangkan cronbach's alpha mengukur nilai terendah (lower bound) reliabilitas suatu variabel sehingga nilai Composite reliability selalu lebih tinggi dibandingkan nilai cronbach's alpha (Jogiyanto, 2016). Berikut adalah nilai cronbach's alpha dan composite reliability masing-masing variabel pada penelitian ini.

Tabel 15 Composite Reliability dan Cronbach's Alpha

\begin{tabular}{|l|c|c|}
\hline \multicolumn{1}{|c|}{ Variabel } & $\begin{array}{c}\text { Composite } \\
\text { Reliability }\end{array}$ & $\begin{array}{c}\text { Cronbach's } \\
\text { Alpha }\end{array}$ \\
\hline Affective Commitment & 0.922 & 0.895 \\
\hline POV $^{*}$ Generasi & 1.000 & 1.000 \\
\hline Person Organization Fit & 0.894 & 0.822 \\
\hline Turnover Intention & 0.833 & 0.752 \\
\hline \multicolumn{1}{|c|}{ WPS } & 0.955 & 0.947 \\
\hline
\end{tabular}

Berdasarkan Tabel 15 dapat diketahui bahwa seluruh konstruk dalam penilaian ini cronbach's alpha $>0.6$ dan nilai composite reliability $>0.7$ maka dapat dikatakan bahwa semua construct adalah reliable. Hal ini dapat diartikan bahwa masing-masing konstruk dalam model penelitian memiliki konsistensi internal dalam uji reliabilitas instrumen.

\section{Analisis Inner Model}

\section{Koefisien Determinasi}

Analisis koefisien determinasi dilakukan untuk mengukur seberapa jauh kemampuan sebuah model dalam menerangkan variasi variabel de- 
penden (Ghozali, 2012). Nilai koefisien determinasi adalah antara nol dan satu. Semakin kecil nilai $R$-square berarti variasi variabel dependen yang sangat terbatas, dan nilai yang mendekati 1 (satu) berarti variabel-variabel independen sudah mampu memberi semua informasi yang dibutuhkan untuk menjelaskan dan memprediksi variabel dependen.

\section{Tabel 16 Nilai R-Square}

\begin{tabular}{|l|c|}
\hline \multicolumn{1}{|c|}{ Variabel } & R-Square \\
\hline Affective Commitment & 0.655 \\
\hline Turnover Intention & 0.816 \\
\hline
\end{tabular}

Berdasarkan nilai $R$-square yang telah ditampilkan pada Tabel 16 dan setelah dikaitkan dengan $100 \%$ maka didapat nilai koefisien determinasi dari affective commitment sebesar $65,5 \%$, dari nilai tersebut menjelaskan bahwa variabel affective commitment dapat dijelaskan oleh variabel person organization fit dan workplace spirituality sedangkan sisanya sebesar $34.5 \%$ dijelaskan oleh variabel lain di luar model penelitian. Sementara nilai koefisien determinasi dari turnover intention sebesar $81.6 \%$ menjelaskan bahwa variasi nilai variabel turnover intention dapat dijelaskan oleh variabel affective commitment dan generasi milenial sedangkan sisanya sebesar $18.4 \%$ dijelaskan oleh variabel lain di luar model penelitian.

\section{Predictive Relevance}

Predictive relevance pada model struktural digunakan untuk mengukur seberapa baik nilai observasi dihasilkan oleh model dan juga estimasi parameternya (Ghozali, 2012). Nilai dari predictive relevance dapat diketahui melalui perhitungan $Q$-square sebagai berikut:

$$
\begin{aligned}
Q \text {-square } & =1-\left[\left(1-R^{2} 1\right) \times\left(1-R^{2} 2\right)\right] \\
& =1-[(1-0.655) \times(1-0.816)]
\end{aligned}
$$

$$
\begin{aligned}
& =1-(0,345 \times 0,184) \\
& =1-0,0634 \\
& =0,9366
\end{aligned}
$$

Berdasarkan hasil perhitungan $Q$-square tersebut maka dapat dinyatakan bahwa model memiliki nilai predictive relevance sebesar 0.9366 atau $93,66 \%$, hal ini menunjukkan bahwa model analisis memiliki predictive relevance yang baik.

\section{Goodness of Fit}

Goodness of fit merupakan pengujian kecocokan atau kesesuaian antara hitungan hasil pengamatan (frekuensi pengamatan) tertentu dengan frekuensi yang diperoleh berdasarkan nilai harapannya (frekuensi teoretis), dari hasil pengolahan data dapat diketahui melalui perhitungan berikut.

$$
\begin{aligned}
\text { Goodness of fit } & =\sqrt{A V E \times R^{2}} \\
& =\sqrt{0,7212 \times 0,7355} \\
& =0.728285
\end{aligned}
$$

Berdasarkan perhitungan tersebut, dapat diketahui bahwa nilai goodness of fit pada penelitian ini sebesar 0.72 . Goodness of fit memiliki tiga kriteria, yaitu $\mathrm{GoF}=0,10$ bernilai kecil, $\mathrm{GoF}=0.25$ bernilai sedang, $\mathrm{GoF}=0,36$ bernilai besar. Hasil perhitungan tersebut menunjukkan jika performa gabungan antara model pengukuran dan model struktural memiliki nilai besar tersebut 0.36. Hal ini menjelaskan bahwa data empiris cocok atau sesuai dengan model (tidak ada perbedaan antara model dengan data sehingga model data dikatakan fit) (Ghozali, 2012).

\section{Uji Pengaruh Langsung}

Uji hipotesis pada penelitian ini dilakukan dengan estimasi koefisien jalur yang dapat dievaluasi berdasarkan nilai T-statistik. Item 
pengukuran yang digunakan dikatakan signifikan apabila nilai T-statistik lebih besar dari 1.96 dan nilai $p$-value kurang dari 0.05 pada taraf signifikansi 5\%. Sedangkan koefisien parameter menunjukkan arah pengaruh dengan melihat positif atau negatifnya original sample sekaligus besarnya pengaruh variabel independen terhadap variabel dependen (Ghozali, 2008). Berikut adalah tabel path coefficient untuk melihat nilai T-statistik.

Tabel 17 Path Coefficient

\begin{tabular}{|c|r|l|r|l|}
\hline Hub. & $\begin{array}{c}\text { Original } \\
\text { Sample }\end{array}$ & $\begin{array}{c}\mathrm{T} \\
\text { Statistics }\end{array}$ & $\begin{array}{c}\mathrm{P} \\
\text { Values }\end{array}$ & Hasil \\
\hline $\mathrm{Z} 1->\mathrm{Y}$ & -0.269 & 3.334 & 0.001 & Signifikan \\
\hline $\mathrm{Z} 2->\mathrm{Y}$ & -0.123 & 2.331 & 0.020 & Signifikan \\
\hline $\mathrm{X} 1->\mathrm{Z} 1$ & 0.322 & 3.679 & 0.000 & Signifikan \\
\hline $\mathrm{X} 1->\mathrm{Y}$ & -0.213 & 3.504 & 0.001 & Signifikan \\
\hline $\mathrm{X} 2->\mathrm{Z} 1$ & 0.604 & 8.045 & 0.000 & Signifikan \\
\hline $\mathrm{X} 2->\mathrm{Y}$ & -0.441 & 5.953 & 0.000 & Signifikan \\
\hline
\end{tabular}

Pada Tabel 17 dapat diketahui bahwa pengaruh person organization fit terhadap turnover intention adalah negative sebesar -0.213 , dengan nilai T-statistik sebesar $3.504>1.96$ dan nilai $\mathrm{p}$ value $0.001<0.05$. Hal ini menunjukkan bahwa person organization fit berpengaruh signifikan negatif terhadap turnover intention. Nilai koefisien jalur pengaruh workplace spirituality terhadap turnover intention adalah negative sebesar -0.441 , dengan nilai T-statistik sebesar $5.953>1.96$ dan nilai p-values $0.000<0.05$. Hal ini menunjukkan bahwa workplace spirituality berpengaruh signifikan negatif terhadap turnover intentions. Nilai koefisien jalur pengaruh person organization fit terhadap affective commitment adalah positif sebesar 0.322, dengan nilai T-statistik sebesar $3.679>1.96$ dan nilai $p$-value $0.000<0.05$. Hal ini menunjukkan bahwa person organization fit berpengaruh signifikan positif terhadap affective commitment. Nilai koefisien jalur pengaruh workplace spirituality terhadap affective commit- ment adalah positif sebesar 0.604 , dengan nilai T-statistik sebesar $8.045>1.96$ dan nilai p-values $0.000<0.05$. Hal ini menunjukkan bahwa workplace spirituality berpengaruh signifikan positif terhadap affective commitment. Nilai koefisien jalur pengaruh affective commitment terhadap turnover intention adalah negative sebesar -0.269 , dengan nilai T-statistik sebesar $3.334>$ 1.96 dan nilai p-values $0.001<0.05$. Hal ini menunjukkan bahwa affective commitment berpengaruh signifikan negatif terhadap turnover intention. Nilai koefisien jalur pengaruh gerenasi milenial memoderasi pengaruh person organization fit terhadap turnover intention adalah negatif sebesar -0.123, dengan nilai T-statistic sebesar $2.331>$ 1.96 dan nilai $\mathrm{p}$-values $0.020<0.05$. Hal ini menunjukkan bahwa generasi milenial memoderasi signifikan negatif hubungan antara person organization fit terhadap turnover intention.

\section{Pengaruh Tidak Langsung}

Tabel 18 Hasil Spesifik Indirect Effects untuk Variabel Mediasi

\begin{tabular}{|c|c|c|c|c|}
\hline Hipo & $\begin{array}{c}\text { Pengaruh Antar- } \\
\text { Variabel }\end{array}$ & $\begin{array}{c}\text { T } \\
\text { Statistics }\end{array}$ & $\begin{array}{c}\text { P } \\
\text { Values }\end{array}$ & Hasil \\
\hline H6 & PO-F - > AC-> ToI & 2.491 & 0.013 & Signifikan \\
\hline H7 & WPS -> AC-> ToI & 2.862 & 0.004 & signifikan \\
\hline
\end{tabular}

Pada Penelitian ini hubungan antara person organization fit sebagai variabel $\mathrm{X}$ terhadap affective commitment yang mana sebagai variabel $\mathrm{Z}$ adalah signifikan (dapat dilihat pada tabel path coefficient). Berdasarkan keterangan tersebut maka dapat disimpulkan bahwa affective commitment dapat memberi pengaruh mediasi antara variabel person organization fit terhadap turnover intention karena hubungan langsung antara kedua variabel terpenuhi begitu pula hubungan antara variabel independen terhadap variabel intervening. Kesimpulan tersebut tentunya didukung dari hasil uji specific indirect pada 
Nevi Nevada, Pengaruh Person Organization Fit dan Workplace Spirituality Terhadap Turnover Intention dengan Affective Commitment sebagai Variabel Intervening dan Generasi Millennial sebagai Moderasi

tabel tersebut yang menunjukkan bahwa nilai Tstatistik pada $\mathrm{H} 6$ adalah $2.491>1.96$ dan nilai p-values $0.013<0.05$. Berikutnya diketahui bahwa hasil uji specific indirect effects untuk variabel mediasi $\mathrm{H} 7$ memiliki nilai $\mathrm{T}$-statistik sebesar $2.862>1.96$ dan p-value 0.004 sehingga affective commitment juga memberi pengaruh mediasi antara variabel workplace spirituality terhadap turnover intention.

Hasil penelitian menunjukkan bahwa kedelapan hipotesis diterima di mana person organization fit memiliki pengaruh terhadap turnover intention, workplace spirituality memiliki pengaruh terhadap turnover intention, person organization fit memiliki pengaruh terhadap affective commitment, workplace spirituality memiliki pengaruh terhadap affective commitment, affective commitment memiliki pengaruh terhadap turnover intention, affective commitment memediasi pengaruh antara person organization dan workplace spirituality terhadap turnover intention, dan generasi millennial memoderasi hubungan antara person organization terhadap turnover intention. Dari hubungan tersebut dapat diartikan bahwa karyawan PT Bank Tabungan Negara, Tbk. memiliki kesesuaian dengan organisasinya dengan begitu tumbuh rasa memiliki terhadap organisasi atau disebut dengan komitmen afektif sehingga karyawan tidak akan memiliki niat untuk berpindah. Hasil penelitian ini sejalan dengan penelitian yang dilakukan oleh Hanich dan Hulin (1990) yang menyatakan bahwa person organization fit dapat meningkatkan kinerja karyawan dan secara tidak langsung dapat menimbulkan dedikasi kepada perusahaan, sehingga dapat menurunkan perilaku turnover intention. Selanjutnya, pengaruh mediasi affective commitment juga terbukti pada hubungan workplace spirituality terhadap turnover intention. Hasil tersebut mendukung penelitian yang dilakukan oleh Kumar dkk. (2012) yang me- nyatakan bahwa workplace spirituality signifikan berpengaruh terhadap affective commitment. Ketika karyawan menemukan makna dalam pekerjaannya, maka secara tidak langsung akan menimbulkan komitmen terhadap perusahaan. Jika dikaitkan dengan kondisi di lapangan bahwa nilai organisasi yang sangat terlihat adalah memedulikan kepentingan masyarakat sosial dan lingkungan secara berkelanjutan, hal ini tentunya sesuai dengan misi Bank Tabungan Negara. Dapat disimpulkan bahwa perusahaan sudah cukup berhasil untuk menyampaikan nilai-nilai perusahaan kepada pegawai di perusahaan tersebut sehingga diterima baik pula oleh para karyawan.

Berdasarkan hasil penelitian di lapangan juga menunjukkan hasil bahwa generasi milenial memoderasi hubungan antara person organization fit terhadap turnover intention. Hasil penelitian ini mendukung hasil penelitian dari Swiggard (2012) yang menyatakan bahwa generasi Y memiliki kecenderungan dua kali lipat lebih besar dari generasi X untuk keluar dari pekerjaannya setelah satu tahun bekerja sehingga salah satu cara untuk meningkatkan loyalitas generasi $\mathrm{Y}$ adalah dengan person organization fit. Ketika karyawan merasa sesuai/fit dengan nilai-nilai perusahaan maka karyawan akan enggan untuk meninggalkan organisasi.

\section{KESIMPULAN}

Berdasarkan hasil pengolahan data dan analisis secara deskriptif maupun statistik maka dari penelitian ini dapat ditarik kesimpulan, yaitu person organization fit berpengaruh signifikan negatif terhadap turnover intention. Workplace spirituality berpengaruh signifikan negatif terhadap turnover intention. Person organization fit berpengaruh signifikan positif terhadap affective commitment. Workplace spirituality berpengaruh signifikan positif terhadap affective 
commitment. Affective commitment berpengaruh signifikan negatif terhadap turnover intention. Affective commitment memediasi hubungan antara person organization terhadap turnover intention. Affective commitment memediasi hubungan antara workplace spirituality terhadap turnover intention. Generasi Millennial memoderasi hubungan antara person organization terhadap turnover intention.

\section{DAFTAR RUJUKAN}

Ali, Syukron. 2016. Mengenal Lebih Dekat Generasi Millennial. Swa.co.id/swa Diakses pada tanggal 15 Maret 2020.

Allen, N.J. \& Meyer, J.P. 1996. Affective, continuance, and normative commitment to the organization: An examination of construct validity. Journal of Vocational Behavior, 49(3), pp.252-276.

Ashmos, D.P. \& Duchon, D. 2000. Spirituality at work: A conceptualization and measure. Journal of Management Inquiry, 9(2), pp.134-145.

Behery, M.H. 2009. Person/organization job fitting and affective commitment to the organization. Cross Cultural Management: An International Journal.

Ghozali, I. 2012. Aplikasi Analisis Multivariate dengan Program IBM SPSS 20. Semarang: Badan Penerbit Universitas Diponegoro.
Jogiyanto. 2016. Metodologi Penelitian Bisnis. Yogyakarta: KPYE IKAPI.

Kicheva, T. 2017. Management of employees from different generations-challenge for Bulgarian managers and HR professionals. Economic Alternatives, 1, pp.103-121.

Kristof, A.L. 1996. Person organization fit: An integrative review of its conceptualizations, measurement, and implications. Personnel Psychology, 49 (1), pp.1-49.

Mathis, R.L. \& Jackson, J.H. 2006. Sumber Daya Manusia. Jakarta: Salemba Empat.

Michaels, C.E. \& Spector, P.E. 1982. Causes of Employee Turnover; A Test of The Mobley, Griffith, Hand, and Meglino Model. Journal of Applied Psychology, 67(1), 53-59.

Panindya, Belfast. 2017. Menjadi Generasi Millennial yang Selalu Kreatif, Aktif, dan Inovatif. www.kompasiana.com/belfast. Diakses pada tanggal 15 Maret 2020

Rachmah, A.N., Machasin, M., \& Fitri, K. 2017. Pengaruh Komitmen Organisasi, Kepuasan Kerja, dan Budaya Organisasi terhadap Turnover Intention pada Karyawan Hotel Mutiara Merdeka Pekanbaru. Doctoral Dissertation, Riau University.

Sugiyono. 2017. Metode Penelitian Kuantitatif Kualitatif dan R\&DD. Bandung: PT Alfabeta. Tanner, L. 2010. Who are the Millennials? Center for Operational Research \& Analysis. Canada: Defence R\&D. 